\title{
Meningkatkan perilaku hidup bersih dan sehat (PHBS) anak usia 4-5 tahun melalui metode bercerita
}

\author{
Pangestuti \\ Pascasarjana Program Studi Pendidikan Dasar, Universitas PGRI Semarang
}

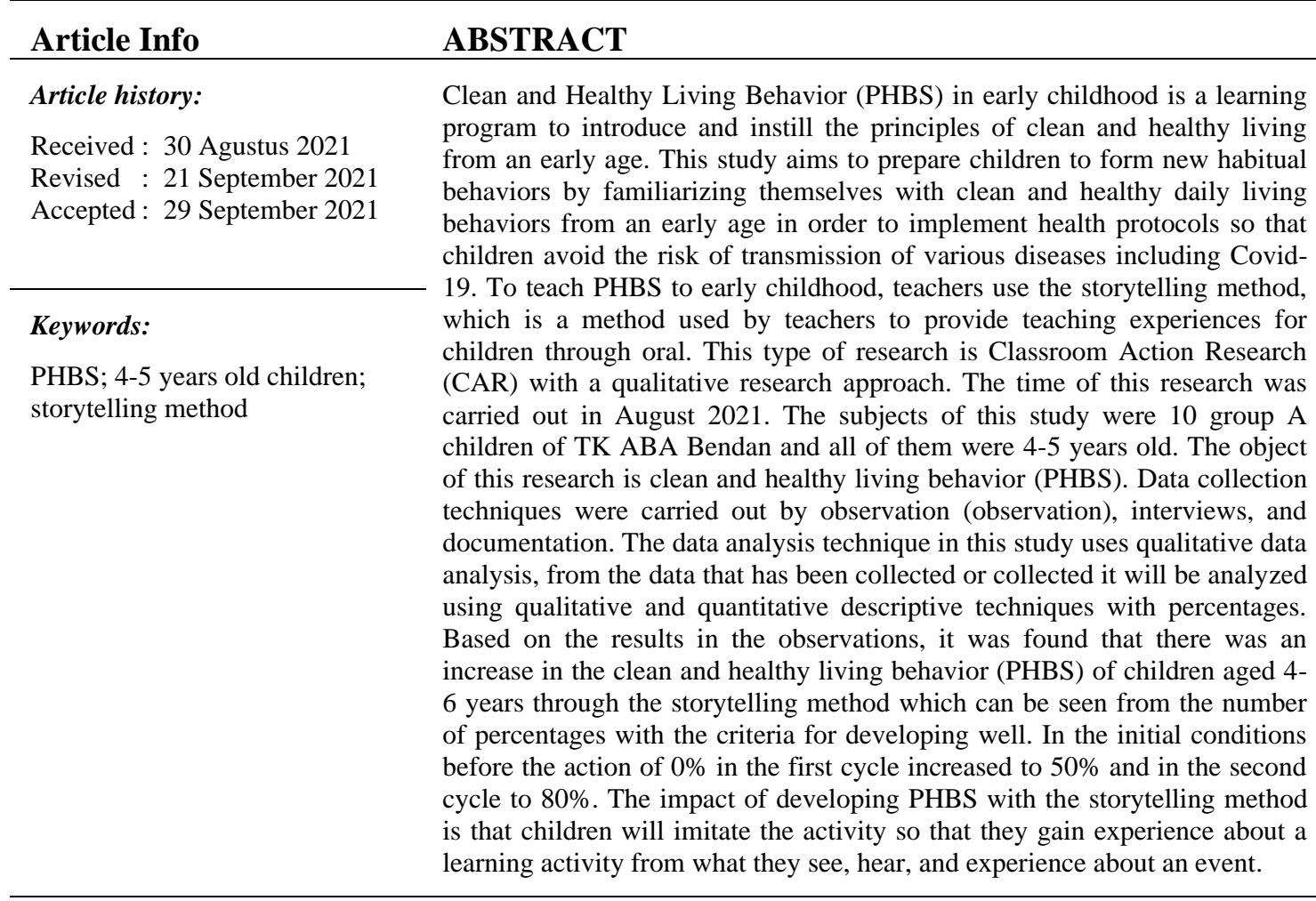

(*) Corresponding Author:

pangestuti.1990@gmail.com

How to Cite: Pangestuti, P. (2021). Meningkatkan perilaku hidup bersih dan sehat (PHBS) anak usia 4-5 tahun melalui metode bercerita. Action Research Journal, 1(1): 108-114.

\section{PENDAHULUAN}

Undang-Undang No. 23/1992 Pasal 1 ayat (1) dalam (Siswanto, 2012). Kesehatan adalah keadaan sejahtera mulai dari badan, jiwa, dan hingga sosial yang memungkinkan setiap orang hidup produktif secara sosial dan ekonomis. Dan diantara kesehatan yang dimiliki oleh masyarakat yang terpenting adalah kesehatan bagi anak usia dini. Anak usia dini yang berumur antara 0-6 tahun atau yang biasanya disebut masa golden age atau usia emas adalah usia yang sangat penting di mana pada anak usia tersebut pada perkembangan fisik, motorik, intelektual, emosional, bahasa dan sosial berlangsung dengan sangat cepat. Seperti dalam (Kemkes RI, 2016) yang disampaikan oleh (Masykuroh, 2020) bahwa salah satu upaya untuk mendukung dapat tercapainya kualitas kesehatan pada anak Indonesia yang lebih baik yaitu program Perilaku Hidup Bersih dan Sehat (PHBS) yang dicanangkan oleh Kementerian Kesehatan Republik Indonesia, dalam arti segala perilaku kesehatan yang dilakukan atas kesadaran pribadi sehingga keluarga dan seluruh anggotanya dapat menolong diri sendiri pada bidang kesehatan serta dapat memiliki peran aktif dalam semua aktivitas masyarakat. PHBS menurut (Kemenkes RI, 2014) dalam (Jauhari, 2020) adalah serangkaian pola perilaku anak yang dilakukan yang 
disebabkan oleh adanya kesadaran dari hasil dari pembelajaran, yang membuat anak dapat memelihara, menjaga kesehatan dan memiliki peran aktif untuk mewujudkan masyarakat yang sehat. Sedangkan PHBS menurut (Madanih, Syahnas Dwi Anjari, \& Abdul Mutholib, 2019) adalah serangkaian perilaku yang dapat diimplementasikan atas dasar adanya kesadaran sebagai hasil suatu pembelajaran dan menjadikan seseorang atau keluarga yang dapat menolong diri sendiri di bidang kesehatan dan berperan aktif dalam mewujudkan derajat kesehatan setinggitingginya.

Saat ini di seluruh dunia termasuk negara Indonesia sedang berada dalam tantangan yang mengharuskan seluruh masyarakat termasuk anak usia dini untuk beradaptasi dengan kondisi berbagai macam penyakit termasuk wabah Corona Virus Disease 2019 (COVID-19) yang sudah menyebar di berbagai penjuru dunia. Sementara program PHBS (Perilaku Hidup Bersih dan Sehat) pada anak usia dini masih berjalan belum optimal yag ditandai dengan adanya berbagai kasus penyakit yang terjadi akibat Perilaku hidup yang kurang sehat. Sebagian dari indikator PHBS anak adalah mencuci tangan dengan menggunkan air mengalir serta sabun, menjaga kebersihan diri, menerapan etika batuk, bersin, dan jaga jaga jarak, pemakaian masker, dan sebagainya. Selain untuk menjaga kesehatan anak-anak dari berbagai macam penyakit yang cepat menular, PHBS juga diperlukan dalam mempersiapkan anak usia dini untuk membentuk pola perilaku kebiasaan baru yang dapat dilakukan dengan membiasakan perilaku sehari-hari sejak dini dalam menerapkan hidup sehat dengan tetap patuh pada protokol kesehatan agar anak dapat terhindar dari segala resiko penularan berbagai penyakit termasuk Covid-19. Pembentukan penerapan kebiasaan baru ini diawali dari peran guru dan orang tua dengan memberikan pengetahuan dan contoh perilaku sehat guna meningkatkan pemahanan pada anak tentang perilaku kebiasaan baru yang dilakukan. Kondisi lingkungan dan komunikasi antara anak dengan guru dan orang tua diperlukan dalam membentuk karakter dan sikap anak terhadap pencegahan terhadap berbagai penyakit yang menular.

Lembaga PAUD yang belum menerapkan adanya pendidikan Perilaku Hidup Bersih dan Sehat (PHBS) dapat berdampak pada kurangnya pembiasaan pola hidup sehat bagi anak usia dini. Jika hal ini tidak ditindak lanjuti, maka akan dapat menimbulkan persoalan dan harus segera ditangani sebelum mereka sebagai anak-anak menjadi korban. Perlu adanya langkah nyata yang harus dilakukan untuk menangani masalah kesehatan khususnya terhadap anak usia dini, maka guru hendaknya mengambil langkah dan tindakan preventif, yakni dengan mencari dan menggunakan suatu model pembelajaran yang efektif, inovatif, dan menarik, dan menyenangkan sebagai alternatif dalam pemecahan masalah tersebut sehingga meningkatkan minat, motivasi dan sikap siswa terhadap perilaku hidup bersih dan sehat (PHBS).

Kemudian Berdasarkan pengamatan atau observasi yang dilaksanakan di kelompok A TK ABA Bendan, diperoleh informasi tentang kondisi dan perilaku hidup bersih dan sehat (PHBS) pada anak. PHBS anak usia 4-5 tahun di kelompok A TK ABA Bendan terdapat kondisi yang beragam dan tergolong masih ada yang masih rendah. Hal ini dapat diamati pada anak ketika peneliti menemukan beberapa anak yang masih kurang menjaga kebersihannya yang ditandai dengan anak belum mampu menjaga kebersihan dirinya, anak masih terlihat suka membuang sampah tidak pada tempatnya, anak juga belum mampu untuk melakukan kegiatan mencuci tangan dengan benar dan runtut, kemudian penerapan pemakaian masker sehari-hari masih belum benar dan konsisten karena masih dipakai tidak menutupi mulut dan hidung secara menyeluruh serta sering dilepas meskipun saat tidak sedang makan dan minum. Serta dalam penerapan etika batuk, bersin, dan jaga jarak anak masih yang belum baik. Selain itu disebabkan karena belum ada penyajian materi yang menarik untuk meningkatkan PHBS anak dalam pembelajaran, sehingga kurangnya pengetahuan anak terhadap bagaimana PHBS untuk diterapkan dalam kehidupan sehari-hari. Oleh karena itu, salah satu cara yang dapat dilakukan adalah dengan menggunakan metode bercerita untuk memberikan pengalaman belajar yang menarik, menyenangkan, bermakna, dan mudah diingat sehingga dapat diterapkan oleh anak dalam kehidupan sehari-hari. 
Metode bercerita merupakan suatu bentuk kegiatan yang dapat dilaksanakan dalam pembelajaran. Seperti yang disampaikan oleh (Rusniah, 2017) metode bercerita merupakan salah satu pemberian pengalaman belajar bagi anak usia dini dengan cara guru membawakan cerita kepada anak secara lisan. Penyampaian atau penyajian materi pembelajaran secara lisan dalam bentuk cerita dari guru kepada anak agar mampu mendengarkan secara seksama terhadap apa yang disampaikan untuk di pahami, di perhatikan, dan kemudian untuk ditiru dan dilaksanakan oleh anak sebagai sumber belajar. Dengan kegiatan tersebut diharapkan dapat meningkatkan kemampuan anak dalam pembiasaan perilaku hidup bersih dan sehat (PHBS). Hal tersebut juga disampaikan oleh (Julianti, Drs. H. M Nasirun, M.Pd, \& Wembrayarli, S.Pd., M.Sn, 2018) bahwa salah satu bentuk penerapan kemampuan dasar dari anak adalah perilaku hidup bersih dan sehat (PHBS) yang dilakukan anak sehari-hari, guru menerapkan perilaku hidup bersih dan sehat melalui pembiasaan rutin melalui nasehat dan cerita yang disampaikan oleh guru.

Anak yang mendapatkan pendidikan dan pembinaan sejak dini tentang kesehatan, diharapkan akan dapat memiliki kebiasaan sehat, pengetahuan tentang kesehatan dan dapat bertanggung jawab untuk berperilaku sehat ketika anak tersebut beranjak dewasa. Anak-anak lebih berpotensi untuk meniru atau melakukan imitasi terhadap perilaku orang dewasa baik melalui kegiatan bercerita dengan tokoh-tokoh yang dianggap menarik untuk anak, dari pada hanya melakukan perintah (suara) maupun intruksi dari orang dewasa di lingkungannya. Orang dewasa harus memberikan pengetahuan dan edukasi yang dapat dengan mudah diserap oleh anak mengenai perilaku hidup bersih dan sehat (PHBS) secara terus menerus atau konsisten dengan benar baik saat dirumah maupun diluar rumah. Dengan begitu, maka anak-anak akan mempunyai pola perilaku hidup bersih dan sehat yang akan dapat dipraktikkan secara mudah oleh anak sehari-hari.

Berdasarkan uraian diatas, peneliti ingin mengetahui apakah terdapat peningkatan yang signifikan terhadap perilaku hidup bersih dan sehat (PHBS) anak usia 4-5 tahun melalui metode bercerita di kelompok A TK ABA Bendan Kota Pekalongan. Rumusan masalah dalam pembahasan ini adalah bagaimana meningkatkan perilaku hidup bersih dan sehat (PHBS) anak usia 4-5 tahun melalui metode bercerita di kelompok A TK ABA Bendan Kota Pekalongan? Tujuan dalam penelitian ini adalah meningkatkan perilaku hidup bersih dan sehat (PHBS) anak usia 4-5 tahun melalui metode bercerita di kelompok A TK ABA Bendan Kota Pekalongan.

Pengembangan perilaku hidup bersih dan sehat (PHBS) melalui kegiatan bercerita memiliki dua manfaat, yaitu manfaat akademis dan manfaat praktis. Secara akademis, hasil penelitian ini diharapkan akan memperluas pengetahuan masyarakat tentang pendidikan kesehatan tentang Perilaku Hidup Bersih dan Sehat (PHBS) anak usia dini dengan kegiatan bercerita. Sedangkan secara praktis, diharapkan dapat menjadi masukan bagi lembaga pendidikan, praktisi, orang tua serta semua pihak terkait dalam pengembangan dan peningkatan mutu pendidikan anak usia dini.

\section{METODE}

Jenis penelitian yang digunakan adalah penelitian tindakan kelas (PTK) dengan pendekatan penelitian kualitatif. Model penelitian yang digunakan peneliti menggunakan model Kemmis dan Taggart berupa perangkat penelitian yang terdiri dari perencanaan, tindakan, pengamatan, dan refleksi. Waktu penelitian ini dilaksanakan pada bulan Agustus 2021. Subjek dari penelitian ini yaitu 10 anak sebagai sampel dari peserta didik kelompok A TK ABA Bendan yang terdiri dari 5 anak laki-laki dan 5 anak perempuan dan seluruhnya berusia 4-5 tahun. Kemudian objek penelitian ini adalah perilaku hidup bersih dan sehat (PHBS) anak didik kelompok A TK ABA Bendan. Data yang dimaksud dalam penelitian ini adalah perilaku hidup bersih dan sehat (PHBS) melalui pengamatan atau observasi. Teknik pengumpulan data dilakukan dengan observasi (pengamatan), wawancara, dan dokumentasi . Teknik analisis data dalam penelitian ini menggunakan analisis data kualitatif, serta dari data yang telah terkumpul atau dihimpun akan dianalisis dengan menggunakan teknik deskriptif kualitatif dan kuantitatif 
dengan persentase. Pada penelitian ini digunakan instrument yaitu berupa lembar observasi. Dimana sebelumnya peneliti menyusun kisi-kisi instrumen terlebih dahulu yang bertujuan agar mempermudah dalam menyusun lembar pengamatan atau observasi yang akan digunakan peneliti untuk mengobservasi anak selama pembelajaran berlangsung. Kisi-kisi instrument yang dibuat adalah sebagai berikut:

Tabel. 1. Kisi-Kisi Instrumen Meningkatkan Perilaku Hidup Bersih dan Sehat (PHBS) Anak Usia 4-5 Tahun Melalui Metode Bercerita Kelompok A TK ABA Bendan Kota Pekalongan

\begin{tabular}{lllcc}
\hline \multicolumn{1}{c}{ Variabel } & Sub Variabel & \multicolumn{1}{c}{ Indikator } & Skor & Kriteria \\
\hline Perilaku Hidup & Metode Bercerita & & 4 & BSB \\
Bersih dan & Mencuci tangan & 3 & BSH \\
Sehat (PHBS) & dengan benar dan & 2 & MB \\
Anak Usia 4-5 & runtut & 1 & BB \\
Tahun & & 4 & BSB \\
& Membuang pampah pada & 3 & BSH \\
& tempatnya & 2 & MB \\
& & 1 & BB \\
& & 4 & BSB \\
& Menjaga & 3 & BSH \\
& kebersihan diri & 2 & MB \\
& & 1 & BB \\
& & 4 & BSB \\
& Pemakaian & 3 & BSH \\
& masker dengan & 2 & MB \\
& benar & 1 & BB \\
& & 4 & BSB \\
& Menerapkan etika & 3 & BSH \\
& batuk, bersin, dan & 2 & MB \\
& jaga jarak & 1 & BB \\
\hline
\end{tabular}

Keterangan:

BB : Belum Berkembang

MB : Mulai Berkembang

BSH : Berkembang Sesuai Harapan

BSB : Berkembang Sangat Baik

Setelah diperoleh hasil observasi kemudian data tersebut dituangkan dalam bentuk presentase. Adapun rumus persentase menurut Suharsimi Arikunto dalam (Imban \& Indriani, 2021) adalah sebagai berikut:

$$
\text { Persentase }(\%)=(\mathrm{n} / \mathrm{N}) \times 100 \%
$$

Keterangan:

$\mathrm{n}=$ Jumlah anak yang memiliki PHBS

$\mathrm{N}=$ Jumlah keseluruhan anak

Kemudian langkah selanjutnya adalah peneliti menentukan indikator keberhasilan dalam penelitian ini jika ada peningkatan dalam perilaku hidup bersih dan sehat (PHBS) anak usia 4-5 tahun kelompok A TK ABA Bendan melalui metode bercerita. Penelitian ini dianggap berhasil jika minimal 75\% dari anak usia 4-5 tahun di kelompok A memperoleh hasil yang baik dengan kategori bekembang sesuai harapan (BSH) dalam menerapkan perilaku hidup bersih dan 
sehat (PHBS). Seperti yang disampaikan oleh (Parapat, 2021) dalam Kriteria berupa persentase kesesuaian menurut Suharsimi Arikunto, yaitu:

1. Kesesuaian kriteria (\%): $0-20=$ Kurang sekali

2. Kesesuaian kriteria (\%): $21-40=$ Kurang

3. Kesesuaian kriteria (\%) : $41-60=$ Cukup

4. Kesesuaian kriteria (\%) : $61-80=$ Baik

5. Kesesuaian kriteria $(\%): 81-100=$ Sangat baik

\section{HASIL DAN PEMBAHASAN}

Hasil

Dari hasil penelitian yang telah dilakukan terjadi adanya peningkatan pada perilaku hidup bersih dan sehat (PHBS) pada anak didik usia 4-5 tahun di kelompok A TK ABA Bendan Kota Pekalongan. Dimana hal tersebut dilaksanakan dalam dua siklus, selama siklus I terdapat tiga kali pertemuan dan siklus II juga terdapat tiga kali pertemuan. Untuk mengetahui perilaku hidup bersih dan sehat (PHBS) anak usia 4-5 tahun kelompok A TK ABA Bendan Kota Pekalongan maka peneliti sebelumnya mengadakan kegiatan pra siklus atau pra tindakan. Selanjutnya berdasarkan hasil pengamatan dan refleksi awal, maka untuk meningkatkan perilaku hidup bersih dan sehat (PHBS) anak usia 4-5 tahun di Kelompok A TK ABA Bendan peneliti merancang kegiatan pembelajaran dengan menggunakan metode bercerita. Sehingga pada pelaksanaanya ternyata pada siklus I belum mencapai taraf keberhasilan yang disebabkan karena masih kurangnya kemampuan anak dalam menerapkan perilaku hidup bersih dan sehat secara konsisten. Oleh karena itu masih perlu adanya perbaikan pembelajaran pada siklus I ke siklus II. Pada kondisi awal yaitu saat pra siklus terdapat 5 anak dengan kriteria Belum Berkembang (BB) mengalami penurunan yang signifikan pada Siklus I menjadi 3 anak dan kemudian pada Siklus II sudah tidak terdapat lagi anak didik dengan kriteria belum berkembang (BB). Pada kriteria Mulai Berkembang (MB) pada kondisi awal terdapat 4 anak, pada Siklus I mengalami penurunan menjadi 1 anak, dan pada siklus II sudah tidak terdapat lagi anak dengan skor demikian. Kemudian pada kriteria berkembang sesuai harapan (BSH) mengalami peningkatan dari kondisi awal masih terdapat 1 anak, menjadi naik pada siklus I yaitu 5 anak, dan pada Siklus II juga naik karena terdapat 8 anak. Sedangkan pada kriteria Berkembang Sangat Baik (BSB) yang semula tidak ada anak yang memperoleh satupun menjadi naik dengan perolehan 1 anak pada siklus I dan menjadi lebih naik lagi pada siklus II yaitu sebanyak 2 anak.

Tabel 2. Analisa Perbandingan Pra Siklus, Siklus I, dan Siklus II Perilaku Hidup Bersih dan Sehat (PHBS) Anak usia 4-5 Tahun Kelompok A

\begin{tabular}{ccccccc}
\hline & \multicolumn{2}{c}{ Pra Siklus } & \multicolumn{2}{c}{ Siklus I } & \multicolumn{2}{c}{ Siklus II } \\
Kriteria & Jumlah & Persen & Jumlah & Persen & Jumlah & Persen \\
Anak & $(\%)$ & Anak & $(\%)$ & Anak & $(\%)$ \\
\hline BB & 5 & $50 \%$ & 3 & $30 \%$ & 0 & $0 \%$ \\
MB & 4 & $40 \%$ & 1 & $10 \%$ & 0 & $0 \%$ \\
BSH & 1 & $10 \%$ & 5 & $50 \%$ & 8 & $80 \%$ \\
BSB & 0 & $0 \%$ & 1 & $10 \%$ & 2 & $20 \%$ \\
\hline
\end{tabular}

Kemudian hasil pengamatan atau observasi kegiatan tersebut dapat dituangkan dalam Gambar 1 sebagai berikut: 


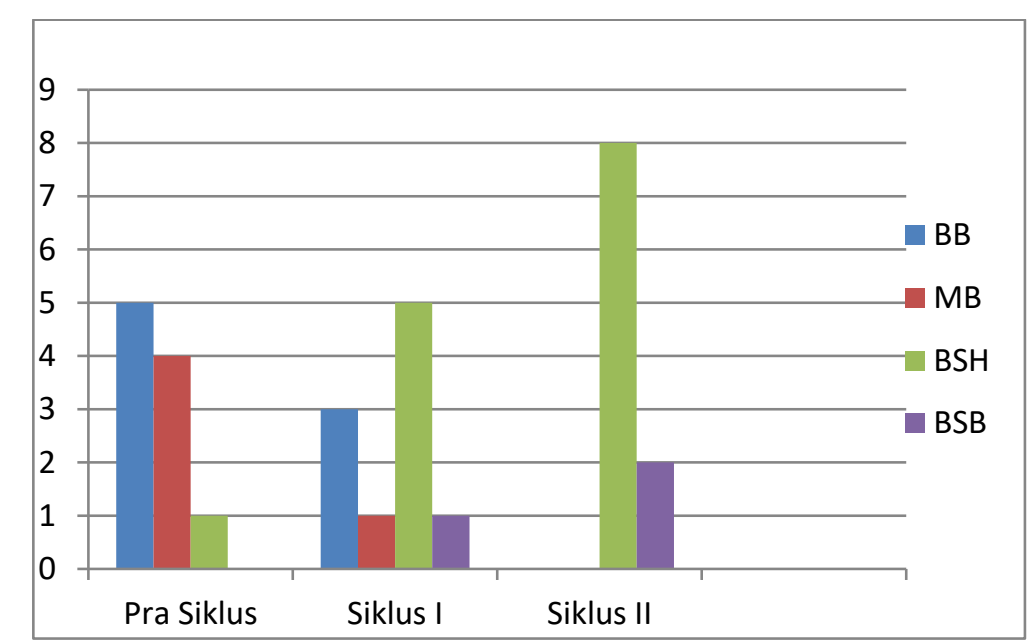

Gambar 1. Peningkatan Hasil PHBS Anak Usia 4-5 tahun Kelompok A

Pada Pra Siklus, Siklus I, dan Siklus II

\section{Pembahasan}

Pada tabel dan gambar hasil yang diperoleh telah menunjukkan bahwa peningkatan perilaku hidup bersih dan sehat (PHBS) anak usia 4-5 tahun kelompok A TK ABA Bendan yang dicapai pada siklus I, belum mencapai keberhasilan yang telah ditetapkan dikarenakan terdapat beberapa hambatan yang ada pada pelaksanaan tindakan siklus I. Hambatan-hambatan tersebut diantaranya: 1). anak belum dapat mencuci tangan dengan benar dan runtut. 2) Masih terdapat anak yang belum terbiasa membuang sampah pada tempatnya, 3) Anak masih harus dibantu oleh guru untuk menjaga kebersihan diri saat kegiatan toilet training, 4) Ada beberapa anak yang belum bisa memakai masker dengan benar dan konsisten karena sering dilepas walaupun tidak saat kegiatan makan dan minum, 5) Anak belum bisa menerapkan etika batuk, bersin, dan jaga jarak dengan teman dan orang lain. Perbaikan yang dilakukan terhadap hambatan-hambatan yang ada pada siklus I, dan dapat menghasilkan peningkatan yang cukup signifikan terhadap perilaku hidup bersih dan sehat (PHBS) anak usia 4-5 tahun yang dicapai oleh anak didik kelompok A pada tindakan siklus II. Dapat dilihat dari hasil yang dapat dicapai pada peningkatan perilaku hidup bersih dan sehat (PHBS) anak usia 4-5 tahun kelompok A saat pra siklus, siklus I, dan siklus II terjadi penurunan skor anak dengan kriteria belum berkembang (BB) yang semula sebanyak 50\% pada pra siklus menjadi 30\% kemudian tidak ada lagi anak dengan skor tersebut, dan kategori mulai berkembang (MB) yang semula sebanyak $40 \%$ menjadi $10 \%$ dan menjadi tidak ada lagi anak dengan kategori tersebut. Sehingga terjadi peningkatan skor anak dengan kategori berkembang sesuai harapan (BSH) yang semula saat pra siklus sebanyak $10 \%$ menjadi $50 \%$ pada siklus I dan kembali naik menjadi sebanyak $80 \%$ pada siklus II. Serta terjadi peningkatan yang semula belum ada menjadi $10 \%$ kemudian naik lagi menjadi 20\% atau 2 anak dari 10 anak jumlah keseluruhan dengan kriteria berkembang sangat baik (BSB). Oleh karena itu hasil akhir dari penelitian ini hanya berakhir sampai pada siklus II saja, karena pencapaian yang diperoleh sebanyak $80 \%$ dengan kategori berkembang sesuai harapan (BSH) yang telah melebihi indikator taraf keberhasilan yaitu sebanyak 75\%, maka dapat diketahui bahwa peningkatan perilaku hidup bersih dan sehat (PHBS) anak usia 4-5 tahun di Kelompok A TK ABA Bendan melalui metode bercerita telah berhasil dan tidak perlu melanjutkan pada siklus selanjutnya.

Metode bercerita dapat digunakan sebagai salah satu sebagai pilihan dalam pembelajaran anak usia dini, khususnya anak usia 4-5 tahun. Metode ini merupakan sarana yang efektif untuk mendidik dan mengajari anak sehingga anak terdorong untuk meniru untuk melakukan hal-hal yang telah diceritakan termasuk tentang penerapan perilaku hidup bersih dan sehat (PHBS).Peningkatan perilaku hidup bersih dan sehat (PHBS ) anak usia 4-5 tahun dipengaruhi oleh metode bercerita yang diterapkan oleh guru karena anak akan memberikan stimulus terhadap anak melalui nilai-nilai budaya yang diketahui oleh anak untuk dilakukan 
imitasi. Hal ini sejalan dengan penelitian lain yang disampaikan oleh Prahesti, et al dalam (Wiyani, 2020) bahwa setiap guru di lembaga PAUD mempunyai peran yang cukup strategis dalam upaya pembudayaan perilaku positif pada anak usia dini. Hal demikian juga sependapat dengan (Imban \& Indriani, 2021) bahwa bukan hanya melalui dicontohkan saja, sebaiknya guru juga perlu mengarahkan, membimbing dan membiasakan anak untuk menerapkan perilaku hidup bersih dan sehat (PHBS)

\section{PENUTUP}

Metode bercerita dapat berperan dalam menumbuhkan perilaku hidup bersih dan sehat (PHBS) anak usia dini. Pada era new normal, metode ini cocok diterapkan di dalam pembelajaran karena dapat membiasakan peserta didik untuk tetap menjaga kesehatan khususnya mematuhi protokol kesehatan dalam kehidupan sehari-hari dari penularan berbagai macam penyakit termasuk dari virus Covid-19. Peningkatan Perilaku hidup bersih dan sehat (PHBS) anak usia 4-6 tahun melalui metode bercerita pada kelompok A TK ABA Bendan Kota pekalongan yang diperoleh dapat dilihat dari jumlah presentasenya dengan kriteria berkembang baik. Pada kondisi awal sebelum tindakan sebesar $10 \%$, kemudian pada siklus I meningkat menjadi $50 \%$ dan pada siklus II menjadi $80 \%$. Penelitian dihentikan sampai siklus II karena sudah memenuhi kriteria keberhasilan yang telah ditentukan yaitu minimal $75 \%$ dari keseluruhan anak. Hal ini dapat terlihat dari hasil kemampuan anak dalam perilaku hidup bersih dan sehat (PHBS) yang meningkat hingga menjadi $80 \%$ dengan kategori berkembang sesuai harapan (BSH) dalam kelima aspek penilaian yaitu mencuci tangan dengan benar dan runtut, membuang sampah pada tempatnya, menjaga kebersihan diri, pemakaian masker dengan benar, dan menerapkan etika batuk, bersin, dan jaga jarak terhadap teman dan orang lain. Dampak dari pengembangan PHBS dengan metode bercerita adalah anak-anak akan meniru kegiatan tersebut sehingga mereka memperoleh pengalaman tentang suatu kegiatan belajar dari apa yang mereka lihat, dengar, dan dari pengalaman tentang suatu kejadian.

\section{DAFTAR PUSTAKA}

Imban, S., \& Indriani. (2021). Meningkatkan Perilaku Hidup Bersih \& Sehat Anak Usia Dini Melalui. Early Childhood Islamic Education Journal, 2 (1), 71-73.

Jauhari. (2020). Perilaku Hidup Bersih Dan Sehat pada Anak Usia Dini. Jurnal Buah Hati, 7, 2. Julianti, R., Drs. H. M Nasirun, M.Pd, \& Wembrayarli, S.Pd., M.Sn. (2018). Pelaksanaan Perilaku Hidup Bersih dan Sehat (PHBS) Di Lingkungan Sekolah. Jurnal Ilmiah Potensia, 3, 12-14.

Madanih, R., Syahnas Dwi Anjari, \& Abdul Mutholib. (2019). Penyuluhan Perilaku Hidup Bersih dan Sehat (PHBS) dengan 7 Langkah Cara Mencuci Tangan yang Efektif di Sekolah PAUD Mawar Kelurahan Sawah Baru, Ciputat, Tangerang Selatan. Prosiding Seminar Nasional Pengabdian Masyarakat LPPM UMJ, 2.

Masykuroh, K. (2020). Implementasi Perilaku Hidup Besih dan Sehat (PHBS) di Sekolah Rujukan Nasional TK Aisyiyah 4 Tebet Jakarta Selatan. Jurnal Penelitian dan Pengembangan Pendidikan Anak Usia Dini, 7, 37.

Parapat, A. (2021). Upaya Meningkatkan Motorik Halus Melalui Origami pada Anak Usia Dini di TK Al-Hikmah. Jurnal of Islamic Early Childhood Education, 1 (1), 9-17.

Rusniah. (2017). Meningkatkan Pekembangan Bahasa Indonesia Anak Usia Dini Melalui Penggunaan Metode Bercerita Pada Kelompok A Di TK Malahayanti Neuhen Tahun pelajaran 2015/2016. Jurnal Edukasi : Jurnal Bimbingan Konseling, 3 (1), 114-130.

Siswanto, H. (2012). Pendidikan Kesehatan Unsur Utama dalam Pendidikan Anak Usia Dini. Jurnal Cakrawala Pendidikan, 5(2), 306-320.

Wiyani, N. A. (2020). Kegiatan Manajerial Dalam Pembudayaan Hidup Bersih dan Sehat Di Taman Penitipan Anak RA Darussalam Kroya Cilacap. Jurnal Isema, 5(1), 16-17. 